•数据论文・

\title{
全球锹甲的几何形态学数据集
}

佟一杰@1,2\#，张萌娜@1,3\#, Josh Jenkins Shaw ${ }^{\circledR 1}$, 万霞 ${ }^{4}$, 杨星科 ${ }^{1,5^{*}}$, 白明①*

1. 中国科学院动物研究所动物进化与系统学重点实验室, 北京 100101; 2. 中国科学院大学, 北京 100049; 3. 深圳市方森园林花卉有限公 司, 广东深圳 518055; 4. 安徽大学资源与工程学院, 合肥 230601; 5. 广东省科学院动物研究所, 广东省动物保护与资源利用重点实验室, 广东省野生动物保护与利用公共实验室, 广州 510260

摘要: 几何形态学是通过定量分析手段对生物的形态特征在几何空间中的变化进行测量, 并将这些测量得到的信息转变为 数字信息进行统计学分析以达到形态特征间比较的目的, 目前被越来越多地用于探索生物的特征进化和多样性研究。先前的 研究通常提取、比对生物的间断性特征信息用以类群之间的划分, 针对连续性特征研究的缺乏使得有关生物进化和形态学的 相关知识变得贵乏。锹甲(鞘翅目：锹甲科)由于其性二型、雄虫多型性和独特的习性成为形态学研究的重要类群。基于此，本 研究中我们提供了一个包含 1,302 种锹甲成虫(涵盖全世界 $99 \%$ 已知种)的形态学数据集, 数据集包含锹甲的典型的连续性特 征, 即前胸背板和鞘翅的外轮廓形态。我们提供的数据集为甲虫的生物多样性、系统发育和进化生物学在内的多个学科的研 究提供基础。

关键词: 几何形态学; 锹甲；连续性特征；前胸背板；鞘翅

数据库(集)基本信息简介

\begin{tabular}{ll} 
数据库(集)名称 & 全球锹甲的几何形态学数据集 \\
作者 & 佟一杰, 张萌娜, Josh Jenkins Shaw, 万霞, 杨星科, 白明 \\
通迅作者 & 杨星科(yangxk@ioz.ac.cn), 白明(baim@ioz.ac.cn) \\
时间范围 & 2019年 \\
地理区域 & 全球 \\
文件大小 & $929.48 \mathrm{~KB}$ \\
数据格式 & .tps, .xlsx \\
数据链接 & http://www.dataopen.info/article/204 \\
& http://doi.org/10.24899/do.202104001 \\
& https://www.biodiversity-science.net/fileup/1005-0094/DATA/2021160.zip \\
数据库(集)组成 & 数据集共包括3个文件: (1) Morphological dataset of pronotum.zip, 是所有锹甲测试样本的前胸背板的标点数据, 数据量 \\
& 274.65 KB; (2) Morphological dataset of elytron.zip, 是所有锹甲测试样本的鞘翅的标点数据, 数据量499.83 KB; (3) \\
& Classification.zip, 是所有锹甲测试样本的分类信息数据, 数据量155 KB。 \\
\hline
\end{tabular}

佟一杰, 张萌娜, Josh Jenkins Shaw, 万霞, 杨星科, 白明 (2021) 全球锹甲的几何形态学数据集. 生物多样性, 29, 1159-1164. doi: 10.17520/biods. 2021160.

Tong YJ, Zhang MN, Jenkins Shaw J, Wan X, Yang XK, Bai M (2021) A geometric morphometric dataset of stag beetles. Biodiversity Science, 29, 1159-1164. doi: 10.17520/biods.2021160.

\section{A geometric morphometric dataset of stag beetles}

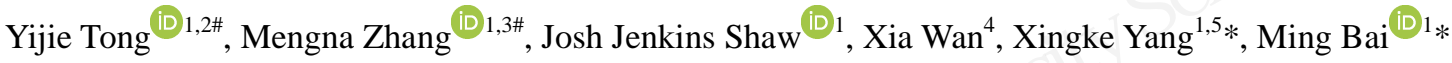

1 Key Laboratory of Zoological Systematics and Evolution, Institute of Zoology, Chinese Academy of Sciences, Beijing 100101

2 University of Chinese Academy of Sciences, Beijing 100049

3 Shenzhen Fangsen Gardening \& Flowers Co., Ltd, Shenzhen, Guangdong 518055

4 School of Resources \& Engineering, Anhui University, Hefei 230601

5 Guangdong Key Laboratory of Animal Conservation and Resource Utilization, Guangdong Public Laboratory of Wild Animal

收稿日期: 2021-04-26; 接受日期: 2021-05-21

基金项目: 国家科技基础资源调查专项(2019FY100400); 国家自然科学基金(31961143002)和中国科学院“一带一路”科技合作行动专项

\# 共同第一作者 Co-first authors

* 共同通讯作者 Co-authors for correspondence. E-mail: baim@ioz.ac.cn; yangxk@ioz.ac.cn 
Conservation and Utilization, Institute of Zoology, Guangdong Academy of Sciences, Guangzhou 510260

\begin{abstract}
Stag beetles (Coleoptera: Lucanidae) have become an important model group for morphological research due to their sexual dimorphism, male polymorphism, and unique behaviors. Here we present a preliminary database of geometric morphometrics for 1,302 stag beetles, which includes nearly 99\% of described species from around the world. This new dataset comprises morphological information from two continuous traits, the curves of the pronotum and elytron, both of which are typical characters of stag beetles. Two curves were measured from the left contours of the pronotum and elytron to represent their external forms. Curve 1 was measured from the middle of the anterior margin of the pronotum to the middle of the posterior margin of the pronotum. Curve 2 started from the anterior margin of the left elytron and terminated at the rear edge. Each curve was resampled into 25 and 50 equally spaced semi-landmarks, respectively. Our dataset provides a baseline for future research in several disciplines, including biodiversity, phylogeny and evolutionary biology.
\end{abstract}

Key words: geometric morphometrics; stag beetle; continuous characters; pronotum; elytron

\title{
Database/Dataset Profile
}

\begin{tabular}{|c|c|}
\hline Title & A geometric morphometric dataset of stag beetles \\
\hline Authors & Yijie Tong, Mengna Zhang, Josh Jenkins Shaw, Xia Wan, Xingke Yang, Ming Bai \\
\hline Corresponding authors & Xingke Yang (yangxk@ioz.ac.cn), Ming Bai (baim@ioz.ac.cn) \\
\hline Time range & 2019 \\
\hline Geographical scope & Global \\
\hline File size & $929.48 \mathrm{~KB}$ \\
\hline Data format & .tps, .xlsx \\
\hline Data link & $\begin{array}{l}\text { http://www.dataopen.info/article/204 } \\
\text { http://doi.org/10.24899/do.202104001 } \\
\text { https://www.biodiversity-science.net/fileup/1005-0094/DATA/2021160.zip }\end{array}$ \\
\hline Database/Dataset composition & $\begin{array}{l}\text { The dataset consists of } 3 \text { subsets in total: Morphological dataset of pronotum.zip is the punctuation data of the } \\
\text { pronotum of all stag beetle test samples, the data volume is } 274.65 \mathrm{~KB} \text {; (2) Morphological dataset of elytron.zip is } \\
\text { the punctuation data of the elytra of all stag beetle test samples, the data volume is } 499.83 \mathrm{~KB} \text {; (3) Classification.zip } \\
\text { is the classification information data of all the stag beetle test samples, the data volume is } 155 \mathrm{~KB} \text {. }\end{array}$ \\
\hline
\end{tabular}

形态比较的起源可以追溯到史前时期，由其发 展出的形态学是自然科学、材料科学和工程学的重 要基础和信息来源(MacLeod, 2017)。几何形态学 (Geometric Morphometrics)兴起于20世纪80年代至 90 年代 (Bookstein, 1986, 1989, 1991; Rohlf \& Bookstein, 1990), 研究者们试图从复杂的形态信息 (Bookstein, 1997; Ricklefs, 2012; Farré et al, 2013; Kozak \& Wiens, 2016)中提取待测样本的形状数据 集(shape dataset), 从而将形态分析手段综合于统一 的方法中进行分析(MacLeod, 2017)。基于这种定量 的分析手段, 传统形态学研究受到主观因素 (Bouchard et al, 2011)以及二维线性距离分析(Fisher, 1938; Rao, 1948)的影响, 所面临的难于标准化获 取、比较特征的形态信息(Smith, 1988; Vihelmsen, 2019; Polidori et al, 2020)等问题得到解决。几何形 态学通过种内及种间固有的可比性, 在拓扑同源点 的位置上呈现小范围差异(MacLeod, 2017), 从而为 长久以来不易获取和进行比较的连续性特征的差
异分析提供了新的思路。当前的大部分几何形态学 研究基于间断性特征对地理种群间的形态差异进 行比较(索中毅等, 2015; Francoy et al, 2016; Zhang et al, 2019), 尚无关于连续性特征在高级阶元的形 态学和生物进化研究中是否具有重要意义的探究 工作(Zhang et al, 2019; Tong et al, 2021)。

锹甲科昆虫广泛分布于除南极洲以外的各大 洲(Mizunuma, 1994; Kim \& Farrell, 2015), 全世界 已有 100 属 1,300种的锹甲被记录 (Benesh, 1960; Pinratana \& Maes, 2002; Fujita, 2010)。锹甲特殊的性 二型和雄虫多型现象长期以来吸引了大量学者关 注(Fujita, 2010; Bai et al, 2015; Monte et al, 2016; 佟 一杰等, 2016), 多样的形态结构变化也使得这一类 群成为了很好的形态学研究对象。前胸背板 (pronotum) 和鞘翅 (elytron) 是甲虫背面观占比最大 的连续性特征, 因其丰富的形态多样性及强大的功 能, 在锹甲进化和分类学研究中具有重要意义, 前 者为前胸内肌肉系统和前足的运动(Evans, 1977; 
Chapman, 1998)提供了重要的支持作用; 后者的形 成使得锹甲的后翅及柔软的腹部受到更好的保护, 从而对周围环境的适应能力大大提升(Van de Kamp \& Greven, 2010; Beutel \& Leschen, 2011)。

本文中, 我们首次提供了一份基于几何形态学 手段获取的前胸背板及鞘翅的形态数据集, 该数据 集涵盖全世界99\%已描述的锹甲物种。本文的目的 是通过该数据集提高对连续性特征的标准化获取 和分析的认识, 同时为后续的多特征比较研究或其 他类群的形态学分析工作创造条件, 对连续性特征 形变的意义进行更为系统的评估。本数据集可用于 多方面的探索工作: (1)量化后的连续性特征所包含 的形态信息在昆虫分类中的应用; (2)生物进化过程 中连续性特征和间断性特征的加权策略的探究; (3) 结合几何形态学和系统发育信息获取生物祖先的 特征信息。

\section{数据采集和处理方法}

\section{1 数据预处理}

我们建立了一个包含锹甲科4亚科(所有现生亚 科) 9族(所有现生族) 104属(所有现生属) 1,302种 (99\%的世界已描述种)锹甲 (Akiyama \& Ohmono, 2000; Kim \& Farrell, 2015)的形态数据集(表1)。测试 样本选取锹甲的标准背面观图片, 样本图片无污点 覆盖、有足够分辨率(至少90 pixel), 方便对其进行 形态学标记分析。所有测试图像文件按照统一的格 式进行命名: 亚科-族-属-种(Bouchard et al, 2011), 便于后续数据分析。

\section{2 数据的采集}

首先, 数据集中的形态学信息取自锹甲样本的 前胸背板和鞘翅的左侧外轮廓(图1)。曲线 1(Curve 1) 由前胸背板前缘的中点起至前胸背板的后缘中点
止; 曲线2 (Curve 2) 由鞘翅的前缘与小盾片末端交 界处起至鞘翅侧缘端点止。前胸背板和鞘翅的外轮 廓曲线分别按照长度均等分为25/50个半标点 (semi-landmark) 以保证其形态信息被完整地提取 (图1)。通过软件TPS-Utility (Version: 1.64)和TPSDIG (Version: 2.05) (Rohlf, 2005; Bai et al, 2014; Tong et al, 2021) 将所有曲线和半标点数据化。其次, 通过文本编辑器打开TPS文件, 将数据中的曲线标 号以及半标点信息删除并将半标点信息替换为标 点信息(Rohlf, 2010; Zhang et al, 2019), 获得的新数 据集保存用于后续几何形态学分析。同时, 本研究 展示了锹甲科下的族级类群的前胸背板和鞘翅的 形态变化情况(由前三个主要成分表示: PC1-PC3), 用于指示分散在形态空间(PC coordinates' space)中 的测试特征沿主成分轴正方向上的形变趋势(图2)。 特征的形变图由主成分轴负极值处的红色逐渐过 渡至正极值处的蓝色, 以便更加直观地展示各测试 类群对应的形态变化程度。

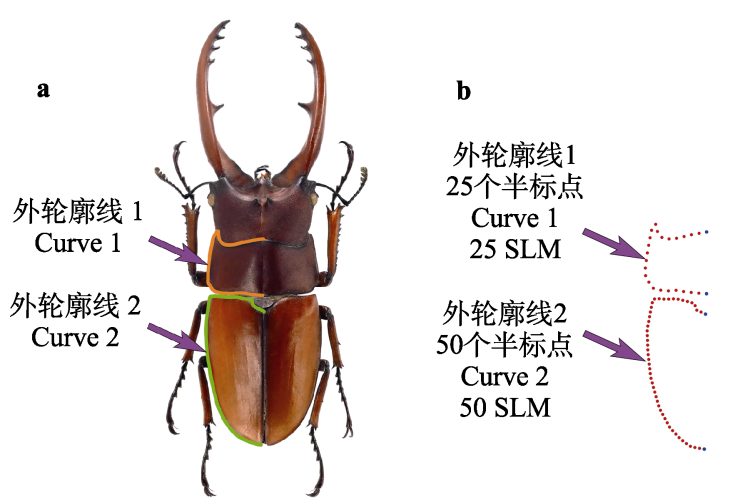

图1 几何形态学分析中的测试曲线(a)及半标点(SLM)(b) 的标注(图示为Pristoderus viridipictus)

Fig. 1 Description of the curves (a) and semi-landmarks (SLM) (b) used in the geometric morphometric analysis (Pristoderus viridipictus)

表1 测试亚科类群的取样信息

Table 1 The sampled information of each subfamily

\begin{tabular}{|c|c|c|c|}
\hline $\begin{array}{l}\text { 测试亚科级类群 } \\
\text { Test subfamily-level group }\end{array}$ & $\begin{array}{l}\text { 族级阶元样本量 } \\
\text { Number of tribes sampled }\end{array}$ & $\begin{array}{l}\text { 属级阶元样本量 } \\
\text { Number of genera sampled }\end{array}$ & $\begin{array}{l}\text { 种级阶元样本量 } \\
\text { Number of species sampled }\end{array}$ \\
\hline 斑纹锹甲亚科 Aesalinae & 3 & 7 & 41 \\
\hline 金锹甲亚科 Lampriminae & 2 & 5 & 11 \\
\hline 锹甲亚科 Lucaninae & 4 & 89 & 1,225 \\
\hline Syndesinae & 0 & 3 & 25 \\
\hline 总计 Total & 10 & 104 & 1,302 \\
\hline
\end{tabular}



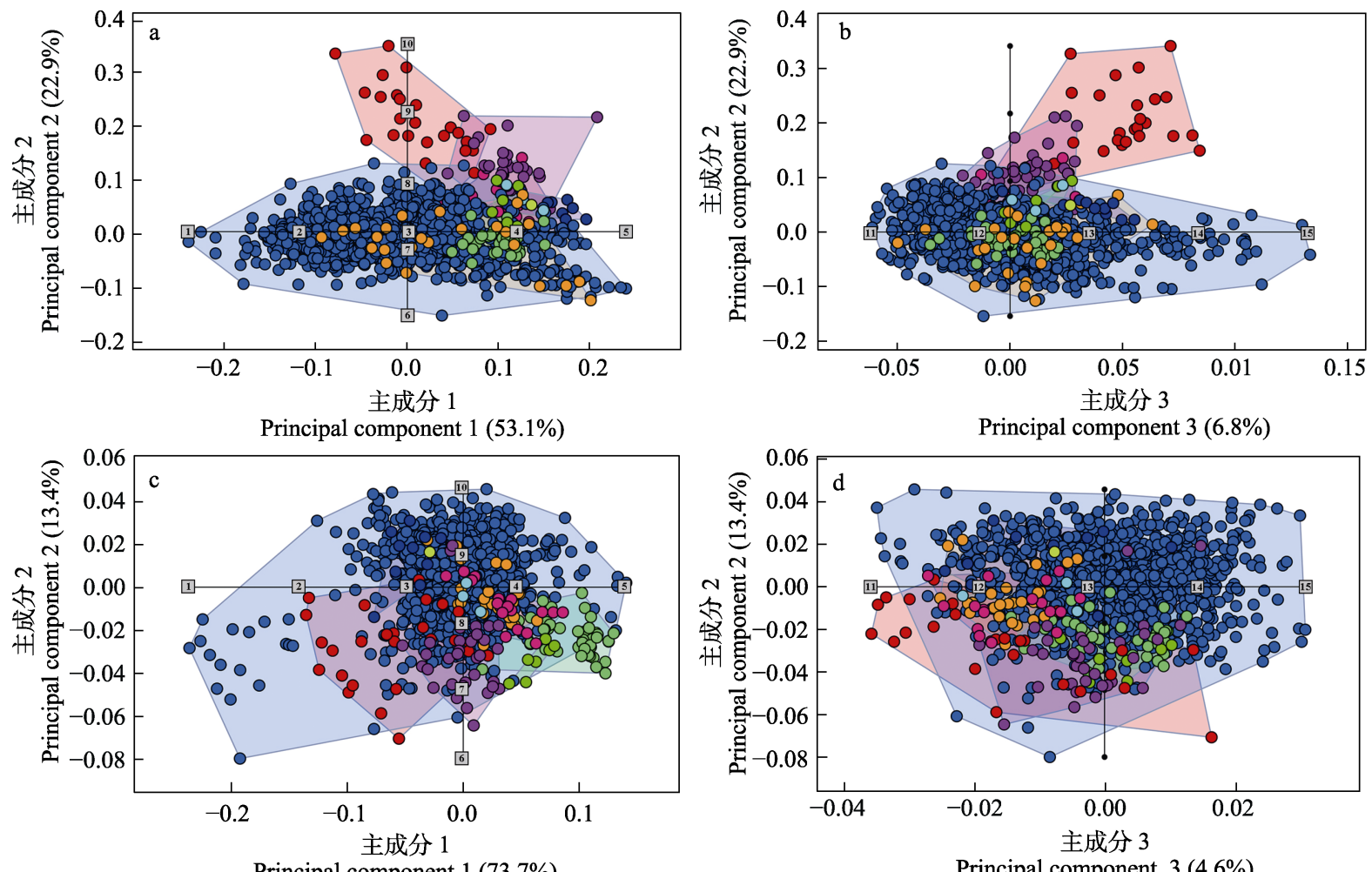

Principal component 1 (73.7\%)

Principal component $3(4.6 \%)$

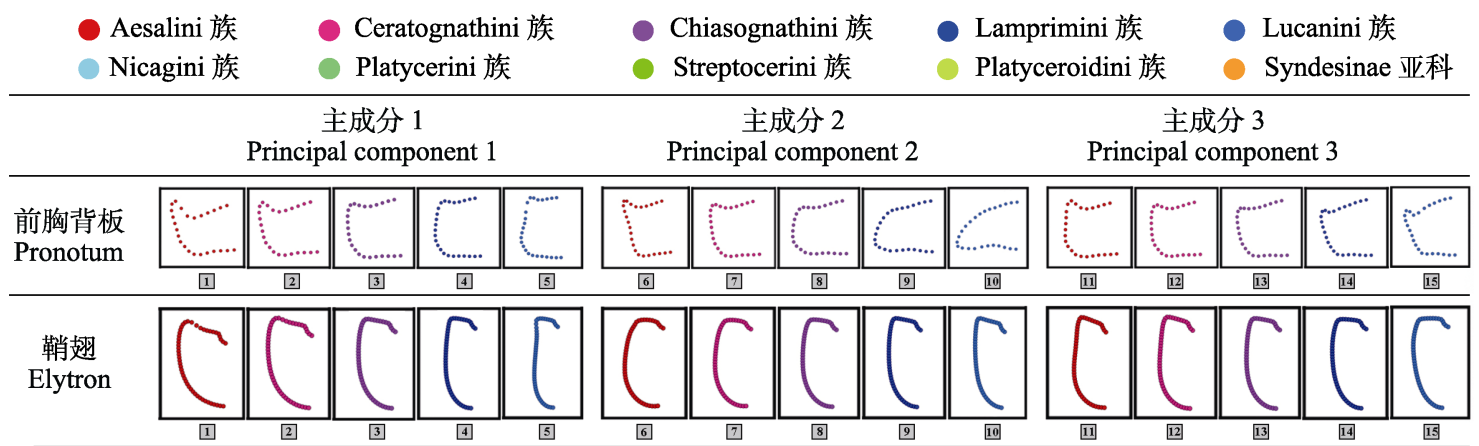

图2 锹甲科的测试特征的形态变化(族级阶元)。a, 前胸背板沿主成分轴 1 和主成分轴 2 的形态变化; $b$, 前胸背板沿主成分轴 2 和主成分轴 3 的形态变化; $\mathrm{c}$, 鞘翅沿主成分轴 1 和主成分轴 2 的形态变化; d, 鞘翅沿主成分轴 2 和主成分轴 3 的形态变化。

Fig. 2 Deformation trend of test characters (tribe-level test) in lucanid beetles. a, Deformation trend of the pronotum along PC1 and PC2. b, Variation of the pronotum along PC2 and PC3. c, Variation of the elytron along PC1 and PC2. d, Variation of the elytron along PC2 and PC3.

\section{2 数据描述}

样本图片主要来源于本实验室的历史积累, 含 历届研究生毕业论文、专著、世界各主要博物馆馆 藏标本、重要文献等(Fujita, 2010)。

一份记录锹甲前胸背板和鞘翅的主文件已上 传至数享(Data-Open), 这份文件中包含 22 份TPS格 式的测试特征形态信息文件, 以及11份Excel格式 的记录锹甲分类地位的说明文件:

(1) 20 份几何形态学标点文件(.tps)。代表了9个 族级类群以及分类系统中不含有族级阶元的
Syndesinae亚科的前胸背板和鞘翅的形态学数据。 所有的形态学数据依据前胸背板/鞘翅进行了 $25 / 50$ 个分布于形态空间的地标点的划分。

(2)与几何形态学标点文件对应的 10 份测试类 群分类地位的说明文件(.csv)。每份说明文件中包含 对该类群中所有测试样本的分类地位的展示, 样本 的分类地位统一进行整理：亚科-族-属-种，以便其 他科研人员更好地使用对应的标点文件。分类地位 说明文件中的样本的列表顺序即为对应的标点文 件中的顺序, 以便快速确定标点文件中测试样本的 分类学地位。 
(3) 2 份整合后的几何形态学标点数据(.tps)及 1 份对应的样本分类地位说明文件(.csv)同样被上传 至数享(Data-Open), 整合标点数据分别包含了所有 测试样本的前胸背板形态学信息及鞘翅的形态学 信息, 方便科研人员根据需要自行选择整合标点数 据/测试类群标点数据。

\section{数据质量控制和评估}

所有样本的形态数据均由同一位研究人员使 用同一款软件进行采集, 以确保采集过程中将人为 干扰降到最低; 此外所有测试样本的形态学数据均 仔细核对检查了 2 遍, 以避免任何可能出现的错误。 为了便于测试特征的准确表达, 所有形态学数据均 取自分辨率足够且未受到污物遮挡的前胸背板及 鞘翅的标准背面观图像。锹甲类群分类地位的确定 工作是参考大多数科研人员所接受的分类标准 (Fujita, 2010; Bouchard et al, 2011), 同时基于相关 领域专家的指导下完成的。

\section{4 数据使用方法和建议}

当使用前胸背板及鞘翅的形态学数据(.tps格式) 时, 请引用本文。该数据集将具有探索不同锹甲类 群间形态差异和系统发育关系的潜在用途。例如, 将几何形态学数据映射到系统发育树上实现锹甲 祖先前胸背板和鞘翅的形态特征的重建, 从而通过 定量分析手段可视化测试特征的形态演化(Zhang et al, 2019); 通过挖掘测试特征在主成分空间中的最 大形变程度可以探索锹甲进化的多元化模型。此外, 除本研究提供的数据集外, 还可以整合更多的几何 形态学软件对数据进一步分析。例如, 通过Morpho J 1.06a (Klingenberg, 2011)对数据集进行主成分分 析 (principal component analysis) 获取测试类群的 Procrustes变异值(通常被视为形态多样性数值), 从 而为该数据集在生物多样性研究中的使用提供支 撑; 通过Morpho J 1.06a (Klingenberg, 2011)对数据 集进行典型变量分析(canonical variance analysis)以 及判别分析(discrimination function analysis)探究不 同阶元类群之间的差异。

致谢: 感谢中国科学院动物研究所鞘翅目形态与进 化研究组为这项研究提供的科研平台, 同时哀心感
谢深圳职业技术学院阮用颖博士为本研究提供的 富有成效的建议。

\section{作者分工}

佟一杰和张萌娜构建数据集; 张萌娜收集锹甲类群的 形态信息; Josh Jenkins Shaw对文稿正文进行审阅; 佟一杰 和万霞对数据集中样本的分类学地位进行厘定; 杨星科对 文稿正文进行审阅; 白明设计本课题思路。

\section{ORCID}

佟一杰 (D) https://orcid.org/0000-0002-6938-9865

张萌娜 (D) https://orcid.org/0000-0002-7265-2038

Josh Jenkins Shaw (D) https://orcid.org/0000-0001-8585-2226 白明 (D) https://orcid.org/0000-0001-9197-5900

\section{参考文献}

Akiyama K, Ohmono S (2000) The Buprestid Beetles of the World. Mushi-Sha Press, Tokyo.

Bai M, Beutel RG, Liu WG, Li S, Zhang MN, Lu YY, Song KQ, Ren D, Yang XK (2014) Description of a new species of Glaresidae (Coleoptera: Scarabaeoidea) from the Jehol Biota of China with a geometric morphometric evaluation. Arthropod Systematics \& Phylogeny, 72, 223-236.

Bai M, Li S, Lu YY, Yang HD, Tong YJ, Yang XK (2015) Mandible evolution in the Scarabaeinae (Coleoptera: Scarabaeidae) and adaptations to coprophagous habits. Frontiers in Zoology, 12, 1-10.

Benesh B (1960) Coleopterorum Catalogus. Part 8. Lucanidea. Springer, Berlin.

Beutel RG, Leschen RAB (2011) Handbook of Zoology, Vol. IV, Part 38, Coleoptera, Beetles, Vol. 1: Morphology and Systematics (Archostemata, Adephaga, Myxophaga, Polyphaga partim). Walter de Gruyter, Berlin.

Bookstein FL (1986) Size and shape spaces for landmark data in two dimensions. Statistical Science, 1, 181-222.

Bookstein FL (1989) Principal warps: Thin-plate splines and the decomposition of deformations. IEEE Transactions on Pattern Analysis and Machine Intelligence, 11, 567-585.

Bookstein FL (1991) Thin-plate Splines and the Atlas Problem for Biomedical Images. Springer, Berlin.

Bookstein FL (1997) Morphometric Tools for Landmark Data: Geometry and Biology. Cambridge University Press, Cambridge.

Bouchard P, Bousquet Y, Davies AE, Alonso ZMA, Lawrence JF, Lyal CHC, Newton AF, Reid CAM, Schmitt M, Slipinski SA, Smith ABT (2011) Family-group names in Coleoptera (Insecta). ZooKeys, 88, 1-972.

Chapman RF (1998) The Insects: Structure and Function. Cambridge University Press, Cambridge.

Evans MEG (1977) Locomotion in the Coleoptera Adephaga, 
especially Carabidae. Journal of Zoology, 181, 189-226.

Farré M, Tuset VM, Maynou F, Recasens L, Lombarte A (2013) Geometric morphology as an alternative for measuring the diversity of fish assemblages. Ecological Indicators, 29, 159-166.

Fisher RA (1938) The statistical utilization of multiple measurements. Annals of Eugenics, 8, 376-386.

Francoy TM, Bonatti V, Viraktamath S, Rajankar BR (2016) Wing morphometrics indicates the existence of two distinct phenotypic clusters within population of Tetragonula iridipennis (Apidae: Meliponini) from India. Insectes Sociaux, 63, 109-115.

Fujita H (2010) The Lucanid Beetles of the World. Mushi-Sha Press, Tokyo.

Kim SI, Farrell BD (2015) Phylogeny of world stag beetles (Coleoptera: Lucanidae) reveals a Gondwanan origin of Darwin's stag beetle. Molecular Phylogenetics and Evolution, 86, 35-48.

Klingenberg CP (2011) MorphoJ: An integrated software package for geometric morphometrics. Molecular Ecology Resources, 11, 353-357.

Kozak KH, Wiens JJ (2016) What explains patterns of species richness? The relative importance of climatic-niche evolution, morphological evolution, and ecological limits in salamanders. Ecology and Evolution, 6, 5940-5949.

MacLeod N (2017) Morphometrics: History, development methods and prospects. Zoological Systematics, 42, 4-33.

Mizunuma T (1994) The Lucanid Beetles of the World. Mushi-Sha Press, Tokyo.

Monte C, Zilioli M, Bartolozzi L (2016) Revision of the Australian species of Figulus MacLeay, 1819 (Coleoptera: Lucanidae). Zootaxa, 4189, 447-484.

Pinratana A, Maes JM (2002) Lucanidae of Thailand. Museo Entomologico de Leon, Leon.

Polidori C, Jorge A, Nieves-Aldrey JL (2020) Comparative morphology of the antennal 'release and spread structure' associated with sex pheromone-producing glands in male Cynipoidea. Zoomorphology, 139, 347-360.

Rao CR (1948) The utilization of multiple measurements in problems of biological classification. Journal of the Royal Statistical Society, Series B (Methodological), 10, 159-203.

Ricklefs RE (2012) Species richness and morphological diversity of passerine birds. Proceedings of the National Academy of Sciences, USA, 109, 14482-14487.

Rohlf FJ, Bookstein FL (1990) Proceedings of the Michigan
Morphometrics Workshop. University of Michigan Museum of Zoology, Michigan.

Rohlf FJ (2005) tpsDig, digitize landmarks and outlines, Version 2.05. Department of Ecology and Evolution, State University of New York at Stony Brook, New York. http://life.bio.sunysb.edu/morph/. (accessed on 2020-09-12)

Rohlf FJ (2010) tpsUtil. Version 1.47. Suny at Stony Brook, Manhattan. https://tpsutil.software.informer.com/. (accessed on 2021-04-08)

Smith DR (1988) A synopsis of the sawflies (Hymenoptera: Symphyta) of America south of the United States: Introduction, Xyelidae, Pamphiliidae, Cimbicidae, Diprionidae, Xiphydriidae, Siricidae, Orussidae, Cephidae. Systematic Entomology, 13, 205-261.

Suo ZY, Bai M, Li S, Yang HD, Li T, Ma DY (2015) A geometric morphometric analysis of the morphological variations among Chinese populations of Protaetia brevitarsis (Coleoptera: Scarabaeidae) with an inference of the invading source of its Xinjiang populations. Acta Entomologica Sinica, 58, 408-418. (in Chinese with English abstract) [索中毅, 白明, 李莎, 杨海东, 李涛, 马德英 (2015) 中国白星花金龟地理变异的几何形态学分析及其 新疆种群的入侵来源推断. 昆虫学报, 58, 408-418.]

Tong YJ, Yang HD, Ma DY, Bai M (2016) Geometric morphometrics evaluation and adaptive evolution study of Scarabaeinae metendosternites. Acta Entomologica Sinica, 59, 871-879. (in Chinese with English abstract) [佟一杰, 杨海东, 马德英, 白明 (2016) 䖾螂后胸叉骨的几何形态 学分析及其适应进化研究. 昆虫学报, 59, 871-879.]

Tong YJ, Yang HD, Josh JS, Yang XK, Bai M (2021) The relationship between genus/species richness and morphological diversity among subfamilies of jewel beetles. Insects, 12, 24.

Van de Kamp T, Greven H (2010) On the architecture of beetle elytra. Entomologie Heute, 22, 191-204.

Vilhelmsen L (2019) Giant sawflies and their kin: Morphological phylogeny of Cimbicidae (Hymenoptera). Systematic Entomology, 44, 103-127.

Zhang MN, Ruan YY, Wan X, Tong YJ, Yang XK, Bai M (2019) Geometric morphometric analysis of the pronotum and elytron in stag beetles: Insight into its diversity and evolution. ZooKeys, 833, 21-40.

(责任编委：黄晓磊 责任编辑：问文杰) 